\title{
KOMPARASI JAKARTA ISLAMIC INDEX DAN FTSE BURSA MALAYSIA HIJRAH SHARIAH INDEX
}

\author{
Nur Fu'ad Shofiyullah \\ Kedutaan Besar Indonesia di Mesir
}

\begin{abstract}
The purpose of this study is to analyze the differences in the performance of the JII Index in Indonesia and FBMHS in Malaysia using the Sharpe, Treynor and Jensen Alpha ratios.

The type of this research is hypothesis testing by using purposive sampling techniques. The population in this study is all listed Islamic Indexes in Indonesia Stock Exchange and Bursa Malaysia. Two Indices are obtained from the sampling process, namely Jakarta Islamic Index (JII) and the FTSE Bursa Malaysia Hijrah Shariah Index (FBMHS). Object of this study is the monthly index return for the period of January 2009 to December 2011, amounting to 36 points of data.

Hypothesis testing is intended to determine whether there are significant differences between the performance of JII and FBMHS on Sharpe, Treynor and Jensen aspects. The tests carried out using Two Independent Samples Mean Comparison. The results showed that there was no significant difference between the performance of JII and FBMHS on the Sharpe, Treynor and Jensen Alpha ratios.
\end{abstract}

Keywords: JII, FBMHS, Sharpe, Treynor, Jensen Alpha

\section{ABSTRAK}

Penelitian ini bertujuan untuk menganalisis perbedaan kinerja indeks Syariah JII di Indonesia dan FBMHS di Malaysia dengan menggunakan rasio Sharpe, Treynor dan Jensen Alpha.

Jenis penelitian ini adalah pengujian hipotesis dengan menggunakan teknik purposive sampling. Populasi pada penelitian ini adalah seluruh indeks Syariah yang terdaftar pada Bursa Efek Indonesia dan Bursa Malaysia. Dari proses pengambilan sampel diperoleh dua indeks yaitu, Jakarta Islamic Index (JII) dan FTSE Bursa Malaysia Hijrah Syariah Index (FBMHS). Objek penelitian ini adalah return bulanan indeks selama periode Januari 2009 hingga Desember 2011 yang berjumlah 36 poin data.

Pengujian hipotesis dimaksudkan untuk mengetahui apakah terdapat perbedaan signifikan antara kinerja JII dan FBMHS pada aspek Sharpe, Treynor dan Jensen. Pengujian dilakukan dengan menggunakan Uji Beda Dua Rata-Rata Sampel Independen. Hasil penelitian menunjukkan bahwa tidak ada perbedaan signifikan antara kinerja JII dan FBMHS pada Rasio Sharpe, Treynor dan Jensen Alpha.

Kata Kunci: JII, FBMHS, Sharpe, Treynor, Jensen Alpha 
Banyak cara untuk melakukan investasi keuangan yang sesuai dengan syariah Islam. Investasi tersebut dapat dilakukan pada berbagai kegiatan usaha yang berkaitan aktivitas menghasilkan suatu produk, aset maupun jasa. Karena itu, salah satu bentuk investasi yang sesuai dengan Syariah Islam adalah membeli Efek Syariah. Efek Syariah tersebut mencakup Saham Syariah, Obligasi Syariah, Reksadana Syariah, Kontrak Investasi Kolektif Efek Beragun Aset (KIK EBA) Syariah, dan surat berharga lainnya yang sesuai dengan prinsip syariah.

Pasar Modal merupakan kegiatan yang bersangkutan dengan penawaran umum dan perdagangan efek, perusahaan publik yang berkaitan dengan efek yang diterbitkannya, serta lembaga dan profesi yang berkaitan dengan efek tersebut (Bapepam LK, 2010). Pasar Modal bertindak sebagai penghubung antara para investor dengan perusahaan ataupun institusi pemerintah melalui perdagangan instrumen keuangan jangka panjang. Sayangnya selama ini pasar modal menjadi wadah ekonomi yang paling banyak menjalankan transaksi yang dilarang seperti bunga (riba), perjudian (gambling/maysir), gharar, penipuan dan lain-lain.

ini Populasi umat Islam di dunia saat

(www.nationmaster.com, 2012) dan Indonesia merupakan negara dengan penduduk Muslim terbesar di dunia dengan populasi mencapai 207 juta jiwa, atau $87,8 \%$ dari total penduduk (BPS, 2010), sedangkan jumlah penduduk Muslim di Malaysia mencapai 17,3 juta jiwa, atau $61,3 \%$ dari total penduduk Malaysia (Department of Statistic Malaysia, 2010). Terkait jumlah umat Islam di dunia secara umun, maupun di Indonesia dan Malaysia secara khusus, perlu dilakukan upaya Islamisasi sektor permodalan sebagai aspek vital perekonomian modern, agar umat Islam dapat berpartisipasi lebih luas.
Selama beberapa tahun terakhir, permintaan untuk produk-produk keuangan berbasis Syariah telah meningkat. Investasi Syariah berkembang signifikan di negara-negara maju dan berkembang pasca tahun 1990 melalui pengenalan reformasi makroekonomi dan struktural yang luas dalam sistem keuangan, penerapan kebijakan liberalisasi perdagangan, pergerakan modal, privatisasi, dan integrasi global pasar keuangan. Kondisi tersebut membuka jalan bagi komunitas Muslim untuk berpartisipasi dalam operasi pasar saham (Dharani dan Natarajan, 2011).

Pada tahun 2011, aset berbasis Syariah berjumlah sebesar USD 939 miliar di seluruh dunia. Sementara terdapat lebih dari 600 dana (fund) Syariah yang tersedia, investor telah mulai menggeser aset mereka dari reksadana yang dikelola secara aktif untuk pasif berbasis indeks investasi ${ }^{1}$.

Pasar modal syariah yang kini memperoleh momentum untuk tumbuh menjadi sebuah pasar yang ramai, terutama untuk pasar berkembang di daerah Timur Tengah, Asia Tenggara, Asia Selatan dan Afrika Utara. Meningkatnya kesadaran dan permintaan untuk investasi sesuai dengan prinsipprinsip Syariah Islam dalam skala global telah menciptakan pasar modal Syariah yang terus berkembang (Ferdian, Dewy dan Riany, 2008).

Indonesia dan Malaysia merupakan dua negara di kawasan Asia Tenggara yang sama-sama memiliki tingkat pertumbuhan saham syariah yang cukup pesat. Di Indonesia, jumlah saham Syariah terus berkembang dan pada Januari 2012 mencapai 252 saham dengan kapitalisasi pasar sebesar Rp. 2.056,61 triliun dan mencakup 56\% dari total nilai kapitalisasi pasar Indeks Harga Saham

\footnotetext{
${ }^{1}$ Shaping a New Tomorrow: Global Wealth 2011, a report by The Boston Consulting Group, May 2011.
} 
Gabungan (IHSG) yang mencapai Rp. $3.665,32$ triliun. $^{2}$

Adapun perkembangan saham Syariah di Malaysia, hingga September 2011 tercatat sebanyak 847 saham dengan kapitalisasi pasar sebesar RM 723 miliar (Rp. 2.167,32 triliun) dan mencakup $62 \%$ dari total nilai kapitalisasi pasar Kuala Lumpur Composite Index (KLCI) yang mencapai RM. 1,17 triliun (Rp. 3.513,28 triliun) ${ }^{3}$.

Fenomena perbedaan jumlah saham syariah yang beredar di Indonesia dan Malaysia dan perkembangannya tersebut menimbulkan pertanyaan, "apakah ada perbedaan kinerja secara agregat antara saham-saham syariah di Bursa Malaysia dengan saham-saham Syariah di Bursa Efek Indonesia?"

$\mathrm{Hal}$ tersebut mendorong penelitian lebih lanjut kinerja sahamsaham Syariah secara agregat melalui perbandingan kinerja index Syariah di Indonesia dan Malaysia. Dalam hal ini penulis mencoba meneliti kinerja Jll di Indonesia dan FTSE Bursa Malaysia Hijrah Syariah Index di Malaysia yang memiliki emiten saham-saham syariah utama dengan kinerja terbaik di kedua negara dengan menggunakan teknik pengukuran risk-adjusted return sebagaimana digunakan dalam portofolio melalui penggunaan variabel rasio Sharpe, Treynor dan Jensen Alpha, serta uji t sebagai uji statistik.

Berdasarkan latar belakang masalah sebagaimana diurakan di atas, maka tujuan penelitian ini adalah menganalisis perbedaan kinerja JII dan FBMHS dengan Rasio Sharpe, Rasio Treynor, dan Rasio Jensen Alpha.

2

http://www.bapepam.go.id/syariah/statistik/pdf/2012 /Statistik_Saham_Januari.pdf

${ }^{3}$ Malaysian ICM, 3rd Quarter 2011, Vol. 6, No 3

\section{TELAAH PUSTAKA}

\section{Investasi, kinerja, return \& risk}

Investasi merupakan komitmen saat ini terhadap sumber daya (dana) yang kita miliki untuk suatu periode waktu tertentu dengan ekspektasi mendapatkan aliran dana masa depan yang mengkompensasi time value of money, ekspektasi inflasi sepanjang umur investasi dan juga menyediakan premium atas ketidakpastian aliran dana di masa depan (Reilly dan Brown, 1999).

Pengukuran kinerja merupakan suatu proses untuk melihat kinerja yang telah terjadi, baik dengan tujuan evaluasi saja, maupun untuk digunakan sebagai bahan pertimbangan pengambilan keputusan pada masa mendatang.

Risiko dan return merupakan dua karakteristik investasi yang penting bagi investor. Investor di pasar modal, sebelum berinvestasi harus terlebih dahulu menetapkan risiko dan return yang ingin dicapai sebagai tujuan investasi.

Return adalah perbedaan antara dana yang kita keluarkan dengan yang kita dapat kembali. Tujuan utama dari berinvestasi adalah untuk memaksimalkan return tersebut. Reilly dan Norton (2006) menjelaskan bahwa return merepresentasikan pertumbuhan kekayaan, dan jika melebihi tingkat inflasi, maka return juga merepresentasikan pertumbuhan daya beli.

Return dapat berupa realized return (imbal hasil realisasi) dan expected return (imbal hasil yang diharapkan). Realized return dihitung berdasarkan data historis, dan digunakan sebagai salah satu pengukur kinerja perusahaan. Realized return juga berguna sebagai penentuan expected return dan risiko di masa yang akan datang. Expected return adalah return yang diharapkan akan diperoleh investor di masa datang (Ross, Westerfield dan Jaffe, 2005). Bila realized return sifatnya sudah terjadi, expected return sifatnya belum terjadi. 
Sedangkan risiko adalah kemungkinan tidak dapat dicapainya tujuan investasi karena ketidakpastian tingkat return pada kurun waktu tertentu (Reilly dan Norton, 2006).

Risiko dapat dikelompokkan dalam dua jenis, yaitu systematic risk dan nonsystematic risk (Reilly dan Norton, 2006). Systematic risk adalah risiko yang timbul dari luar kegiatan perusahaan dan berkaitan dengan kondisi pasar secara keseluruhan seperti resesi ekonomi, inflasi, dan sebagainya. Risiko semacam ini tidak dapat dihilangkan dengan diversifikasi (kombinasi beberapa aset/sekuritas dalam suatu portofolio sehingga dihasilkan tingkat risiko yang lebih rendah). Sehingga systematic risk sering disebut juga dengan undiversifiable risk.

Kebalikan dengan systematic risk, nonsystematic risk atau unsystematic risk dapat dikurangi dengan membentuk portofolio yang well diversified. Karena risiko ini unik untuk tiap perusahaan, maka hal buruk yang terjadi pada suatu perusahaan dapat diimbangi dengan hal yang baik pada perusahaan lainnya. Risiko semacam ini sering disebut juga diversifiable risk.

\section{Jakarta Islamic Index}

Menurut IDX (2010), JII merupakan indeks yang menggunakan 30 emiten yang masuk dalam kriteria syariah (Daftar Efek Syariah yang diterbikan oleh Bapepam-LK, 2012) dan termasuk saham yang memiliki kapitalisasi besar dan likuiditas tinggi.

Berdasarkan arahan Dewan Syariah Nasional dan Peraturan BapepamLK (2010) Nomor IX.A.13 tentang Penerbitan Efek Syariah, jenis kegiatan utama suatu badan usaha yang dinilai tidak memenuhi syariah Islam adalah (IDX, 2010):

1. Usaha perjudian dan permainan yang tergolong judi atau perdagangan yang dilarang.

2. Menyelenggarakan jasa keuangan yang menerapkan konsep ribawi, jual beli resiko yang mengandung gharar dan maysir.

3. Memproduksi, mendistribusikan, memperdagangkan dan atau menyediakan :

a. Barang dan atau jasa yang haram karena zatnya (haram li-dzatihi)

b. Barang dan atau jasa yang haram bukan karena zatnya (haram lighairihi) yang ditetapkan oleh DSN-MUI, dan atau

C. Barang dan atau jasa yang merusak moral dan bersifat mudarat.

4. Melakukan investasi pada perusahaan yang pada saat transaksi tingkat (nisbah) hutang perusahaan kepada lembaga keuangan ribawi lebih dominan dari modalnya, kecuali investasi tersebut dinyatakan kesyariahannya oleh DSN-MUI.

Kriteria saham yang masuk dalam katagori syariah adalah (IDX, 2010):

1. Tidak melakukan kegiatan usaha sebagaimana yang diuraikan di atas.

2. Tidak melakukan perdagangan yang tidak disertai dengan penyerahan barang/jasa dan perdagangan dengan penawaran dan permintaan palsu

3. Tidak melebihi rasio keuangan sebagai berikut:

a. Total hutang yang berbasis bunga dibandingkan dengan total ekuitas tidak lebih dari $82 \%$ (hutang yang berbasis bunga dibandingkan dengan total ekuitas tidak lebih dari $45 \%: 55 \%$ )

b. Total pendapatan bunga dan pendapatan tidak halal lainnya dibandingkan dengan total pendapatan (revenue) tidak lebih dari $10 \%$

\section{Kriteria Pemilihan Saham Jakarta Islamic Index}

Untuk menetapkan saham-saham yang masuk dalam perhitungan Jakarta Islamic Index dilakukan proses seleksi sebagai berikut (IDX, 2010):

a. Saham-saham yang akan dipilih berdasarkan Daftar Efek Syariah 
(DES) yang dikeluarkan oleh Bapepam-LK.

b. Memilih 60 saham dari Daftar Efek Syariah tersebut berdasarkan urutan kapitalisasi pasar terbesar selama 1 tahun terakhir.

c. Dari 60 saham tersebut, dipilih 30 saham berdasarkan tingkat likuiditas yaitu nilai transaksi di pasar reguler selama 1 tahun terakhir.

\section{FTSE Bursa Malaysia Hijrah Syariah (FBMHS)}

Menurut FTSE (2012), FTSE Bursa Malaysia Hijrah Shariah Index dirancang untuk digunakan sebagai dasar produk investasi Syariah yang memenuhi persyaratan screening oleh investor Syariah internasional. Efek yang masuk dalam indeks tersebut disaring oleh Shariah Advisory Council (SAC) Malaysia dan konsultan Syariah global terkemuka, Yasaar Ltd, dengan pedoman yang jelas.

SAC menetapkan bahwa sebuah saham adalah saham syariah antara lain jika tidak terlibat dalam salah satu aktifitas berikut (FTSE, 2012): Jasa keuangan berdasarkan riba (bunga), perjudian, industri atau penjualan produk non-halal atau produk-produk terkait, asuransi konvensional, kegiatan Hiburan yang non-halal menurut Syariah, industri atau penjualan produk berbasis tembakau atau produk-produk terkait , menjadi broker atau melakukan Perdagangan saham non syariah, serta kegiatan lain yang dianggap non-halal menurut Syariah.

Adapun dalam kriteria Yasaar, saham tidak dapat dikategorikan Syariah jika perusahaan yang mengeluarkan antara lain melakukan salah satu dari aktifitas bisnis sebagai berikut (FTSE, 2012): keuangan Konvensional (Perbankan, Keuangan dan Asuransi nonSyariah, dII), alkohol, produk-produk terkait babi dan produksi pangan nonhalal, pengemasan dan pengolahan atau kegiatan lain yang berhubungan dengan daging babi dan makanan non-halal, hiburan (kasino, perjudian, sinema, musik, pornografi dan hotel), tembakau, senjata, amunisi dan industri pertahanan.

Setelah perusahaan disaring aktivitas sektor bisnisnya, keuangan perusahaan diteliti lebih lanjut untuk memastikan bahwa perusahaan tersebut sesuai Syariah. Hanya perusahaanperusahaan yang lulus rasio keuangan sebagai berikut yang akan diberikan label Syariah (FTSE, 2012):

a. Jumlah utang kurang dari $33 \%$ dari total aktiva

b. Kas dan item yang memiliki interest kurang dari 33\% dari total aktiva

c. Piutang dan kas kurang dari $50 \%$ dari total aktiva

d. Jumlah bunga dan pendapatan dari kegiatan non Syariah tidak melebihi $5 \%$ dari total pendapatan

Setelah melalui proses screening di atas, dipilih 30 perusahaan dengan peringkat tertinggi dengan kapitalisasi pasar penuh untuk masuk dalam FTSE Bursa Malaysia Hijrah Index.

\section{Capital Asset Pricing Model (CAPM)}

Kemampuan untuk mengestimasi return saham merupakan hal yang sangat penting dan diperlukan untuk investasi saham. Untuk dapat mengestimasikan return suatu saham dengan baik dan mudah diperlukan suatu model estimasi yaitu dengan menggunakan Capital Asset Pricing Model (Jogiyanto, 2011).

CAPM merupakan model yang menjelaskan hubungan antara return dari semua asset yang berisiko sebagai fungsi dari covariance nya dengan market portofolio. CAPM didasarkan pada teori bahwa investor menginginkan return yang lebih tinggi pada tingkat risiko yang lebih tinggi pula. Model CAPM dapat dijelaskan sebagai berikut (Christian, 2009): 


$$
\begin{aligned}
& \mathrm{E}(\mathrm{Ri})=\mathrm{RFR}+\beta \mathrm{i}[\mathrm{E}(\mathrm{Rm})-\mathrm{RFR}] \\
& \text { Keterangan: } \\
& \mathrm{E}(\mathrm{Ri})=\text { Expected Return pada Capital Asset } \\
& \mathrm{RFR}=\text { Risk Free Rate, ting kat pengembalian tanpa risiko } \\
& \text { bi }=\text { Beta, tingkat volatilitas return asset I terhadap return pasar. } \\
& \mathrm{E}(\mathrm{Rm})=\text { Expected Return of market }
\end{aligned}
$$

Seperti halnya teori keuangan yang lainnya, beberapa asumsi diperlukan untuk mengembangkan model ini. Asumsi-asumsi ini digunakan untuk menyederhanakan persoalanpersoalan yang sesungguhnya terjadi di dunia nyata.

Asumsi-asumsi yang digunakan di model CAPM adalah sebagai berikut ini (Rilley dan Brown, 1999):

a. Semua investor adalah investor efisien yang memiliki target poin efisien, sehingga dalam memilih portofolio akan menyesuaikan dengan kecenderuangan indivisu terkait risiko dan retur yang diharapkan.

b. Semua investor dapat meminjam sejumlah dananya (lending) atau meminjam (borrowing) sejumlah dana dengan jumlah yang tidak terbatas pada tingkat suku bunga bebas risiko.

c. Semua investor mempunyai harapan yang seragam (homogeneous expectation) yaitu mereka memperkirakan distribusi probabilitas return yang identik.

d. Setiap investor Semua investor mempunyai cakrawala waktu satu periode yang sama.

e. Semua aktiva dapat dipecah-pecah menjadi bagian yang lebih kecil dengan tidak tak terbatas. Ini berarti bahwa dengan nilai yang terkecilpun investor dapat melakukan investasi dan melakukan transaksi penjualan dan pembelian aktiva setiap saat dengan harga yang berlaku.

f. Tidak ada biaya transaksi. Penjualan atau pembelian aktiva tidak dikenai biaya transaksi.

g. Tidak terjadi inflasi.

h. Pasar modal dalam kondisi ekuilibrium.
CAPM adalah model ekuilibrium yang meliputi dua hubungan penting, Tandelilin (2010) menjelaskan bahwa hubungan risiko dan return dapat dipandang dari dua konteks, yaitu konteks portofolio efisien dan konteks sekuritas individual. Hubungan antara risiko dan return portofolio efisien akan menghasilkan garis pasar modal (Capital Market Line, CML), sementara hubungan antara risiko dan return sekuritas individual akan menghasilkan garis pasar sekuritas (Security Market Line, SML).

\section{Ukuran kinerja Sharpe}

Pengukuran kinerja metode Sharpe diperkenalkan pertama kali pada tahun 1966 oleh William Sharpe. Pengukuran dengan metode Sharpe didasarkan pada excess return atas risiko atau yang dikenal dengan reward-to-variability ratio. Excess return didapat dari perbedaan atau selisih antara tingkat pengembalian ratarata investasi portofolio dengan investasi yang bebas risiko (Indiastuti, 2008).

Dalam penelitian ini, investasi portofolio merupakan investasi pada masing-masing emiten JII dan FBMHS dan investasi tanpa risiko diasumsikan sebagai tingkat suku bunga rata-rata dari Sertifikat Bank Indonesia (SBI) dan suku bunga overninght Bank Negara Malaysia. Sedangkan standar deviasi portofolio yang dipakai merupakan nilai risiko total yang menggabungkan risiko yang dapat didiversifikasi (unsystematic risk) dan risiko yang tidak dapat didiversifikasi (systematic risk).

\section{Ukuran kinerja Treynor}

Pengukuran dengan metode Treynor juga didasarkan atas excess return (Rp-Rf), seperti halnya Sharpe. Namun, dalam Treynor digunakan pembagi beta $(\beta)$ yang merupakan risiko 
sistematik atau juga disebut risiko pasar (Indiastuti, 2008).

\section{Ukuran kinerja Jensen}

Pengukuran metode Jensen didasarkan atas Capital Asset Pricing Model (CAPM). Model ini menyatakan apakah manajer investasi dapat outperform pada pasar melalui cara yang bisa diprediksi dan significant secara statistik, yaitu dengan ditunjukannya dengan alpha yang positif. Manager Investasi yang baik akan menghasilkan alpha positif yang signifikan dan begitu pula sebaliknya (Jensen, 1968).

Metode ini dikembangkan oleh Michael C. Jensen di tahun 1968. Jensen Alpha mengukur kinerja dengan menghitung perbedaan pengembalian yang diperoleh dari suatu portofolio (actual return) dengan pengembalian yang diharapkan berdasarkan tingkat risiko sistematisnya.

\section{Penelitian Terdahulu}

Walkshäusl dan Lobe (2011) dengan menggunakan sampel internasional yang terdiri dari 35 pasar negara maju dan berkembang menganalisis apakah indeks Islam menunjukkan kinerja yang berbeda dengan indeks konvensional. Meski dari uji rasio Sharpe dan hasil uji risiko pasar ditemukan bahwa tidak ada perbedaan signifikan antara kinerja kedua jenis indeks, namun ditemukan empat faktor alpha positif dan signifikan untuk agregat wilayah pasar negara maju. Kinerja yang rendah tersebut terutama terdapat pada pasar AS dan sebagian besar disebabkan oleh tidak dimasukkannya saham sektor keuangan dalam indeks syariah. Karena adanya penurunan kinerja terkait krisis keuangan terakhir, Walkshäusl dan Lobe (2011) berpendapat bahwa rendahnya kinerja indeks Syariah tidak akan berlangsung terus menerus (akan mengalami perbaikan kinerja jika kondisi pasar telah pulih). Hasil analisis pada gaya (corak) investasi mengungkapkan bahwa Indeks Syariah berinvestasi terutama pada saham yang memiliki pertumbuhan baik dan saham yang memiliki momentum positif. Walkshäusl dan Lobe (2011) menjelaskan bahwa return menjanjikan dari portofolio pasif (pada indeks Syariah) adalah akibat dari alokasi besar terhadap perusahaan sektor energi dan karakteristik momentum mereka yang kuat selama periode penelitian.

Hassan dan Girard (2011) meneliti kinerja tujuh indeks yang dipilih dari Dow Jones Islamic Market Index (DJIM) dibandingkan dengan kinerja indeks konvensional menggunakan berbagai rasio seperti Sharpe, Treynor, Jensen dan selektivitas Fama. Kedua, Hassan dan Girard (2011) juga meneliti kinerja kedua jenis indeks menggunakan model empat faktor pricing Carhart. Ketiga, Hassan dan Girard (2011) menggunakan kointegrasi untuk mengkaji bagaimana kinerja indeks Syariah dibandingkan dengan indeks konvensional. Penelitian ini menggunakan periode sampel dari Januari 1996 sampai Desember 2005 (120 titik data). Hal ini lebih lanjut dibagi menjadi dua sub-periode: Januari 1996 sampai Desember 2000 (60 poin data) dan Januari 2001 sampai Desember 2006 (60 titik data). Hasil penelitian menyimpulkan tidak ada perbedaan kinerja antara indeks Syariah dan konvensional. Kinerja DJIM mengalahkan indeks konvensional pada periode 19962000 dan dan kalah dari indeks konvensional pada periode 2001 sampai 2005. Secara keseluruhan, terdapat efek serupa pada risiko dan manfaat diversifikasi untuk kedua jenis indeks, baik Syariah maupun konvensional.

Dharani dan Natarajan (2011) meneliti resiko dan return dari Nifty Shariah Index dan Nifty Index di India untuk periode 2 Januari 2007 hingga 31 Desember 2010. Penelitian ini menggunakan metode pengukuran risk adjusted melalui Indeks Sharpe, Treynor dan Jensen Alpha, di samping menggunakan uji -t untuk mengetahui perbedaan mean dari return kedua indeks. Penelitian ini mengungkap bahwa Nifty Syariah berkinerja kurang baik selama periode sampel dan periode sub 
sampel. Menurut uji -t, perbedaan mean antara kedua indeks tersebut tidak menunjukkan konsistensi keduanya. Adapun penghitungan risk adjusted return untuk kedua indeks mengungkapkan bahwa keduanya berkinerja buruk terhadap risk free rate of return. Penelitian ini juga mengungkapkan volatilitas Nifty Syariah yang lebih rendah jika dibandingkan dengan Nifty Index. Akhirnya, penelitian ini menyimpulkan bahwa Nifty Syariah dan Nifty Indeks di India memiliki kinerja yang serupa.

Ferdian, Dewi dan Riany (2008) melakukan penelitian komparasi kinerja saham Syariah Indonesia dan Malaysia selama periode Januari 2006 hingga Oktober 2007 dengan menggunakan return saham harian. Antara kedua negara, hasil empiris yang diperoleh dari penelitian ini sampai pada kesimpulan bahwa kinerja saham Syariah Malaysia mengungguli saham Syariah Indonesia. Namun demikian, secara umum penelitian ini menyimpulkan bahwa kinerja saham syariah relatif mengungguli kinerja pasar, sehingga saham Syariah layak dipertimbangkan oleh investor baik konvensional maupun syariah sebagai bagian dari seleksi portofolio mereka.

Albaity dan Ahmad (2008) meneliti kinerja Kuala Lumpur Syariah Index (KLSI) dan Kuala Lumpur Composite Index (KLCl) antara tahun 1999 sampai tahun 2005. Penelitian tersebut membuktikan bahwa tidak ada perbedaan statistik yang signifikan pada risk-adjusted returns antara indeks syariah dan konvensional di Malaysia.

Hussein (2004) meneliti hipotesis yang menyatakan bahwa investasi etis (indeks Syariah) memiliki kinerja lebih rendah jika dibandingkan dengan benchmark (indeks) konvensional, melalui uji empiris apakah return yang diterima oleh investor yang membeli saham FTSE Global Islamic Index berbeda dengan investor pada FTSE All-World Index. Periode sampel dibagi menjadi dua sub-periode, periode Bullish (Juli 1996-Maret 2000) dan periode Bearish (April 2000-Agustus 2003). Melalui perbandingan kinerja raw risk dengan risk-adjusted, diperoleh hasil bahwa FTSE Global Islamic Index memiliki kinerja yang tidak berbeda dengan FTSE AllWorld Index selama seluruh periode. Di sisi lain, Indeks Syariah secara statistik menghasilkan return abnormal positif yang signifikan pada periode Bearish, meskipun pada periode bearish kinerja indeks Syariah di bawah buruk indeks konvensional. Secara umum, penelitian tersebut menyimpulkan bahwa penerapan skrining etis (Syariah) tidak memiliki efek buruk pada kinerja FTSE Global Islamic Index.

Tony (2004) melakukan penelitian dengan membandingkan kinerja Jakarta Islamic Index (JII) sebagai proxy kinerja investasi etis dengan kinerja indeks LQ45, Indeks Harga Saham Gabungan (IHSG) dan indeks sektor keuangan (Finance) sebagai proxy kinerja investasi konvensional. Penelitian dengan metode pengamatan yang berlangsung selama 11 bulan (2 Januari 2003-22November 2003) tersebut menyimpulkan bahwa dengan melakukan perbandingan kinerja secara langsung maupun dengan menggunakan parameter excess return to variability measure atau Sharpe measure dan differential measure dengan risiko sebagai deviasi standar, menunjukkan bahwa kinerja rata-rata return harian, mingguan dan bulanan indeks JII sedikit lebih baik dari indeks lainnya.

Berdasarkan kajian pustaka dan pengembangan hipotesis, maka hipotesis yang dapat dirumuskan dalam model gambar yaitu: 


\begin{tabular}{|c|}
\hline Kinerja Keuangan \\
JII \\
Sharpe \\
Treynor \\
Jensen \\
\hline
\end{tabular}

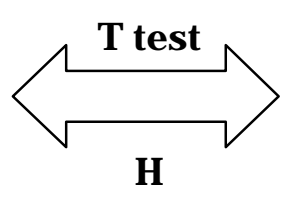

\begin{tabular}{|c|}
\hline Kinerja Keuangan \\
FBMHS \\
Sharpe \\
Treynor \\
Jensen \\
\hline
\end{tabular}

\section{Gambar 1. Kerangka Pemikiran}

Hipotesis dalam penelitian ini dapat dirumuskan sebagai berikut:

$\mathrm{H}_{1}=$ Ada perbedaan kinerja JII dan FBMHS diukur dengan rasio Sharpe

$\mathrm{H}_{2}=$ Ada perbedaan kinerja JII dan FBMHS diukur dengan rasio Treynor

$\mathrm{H}_{3}=$ Ada perbedaan kinerja JII dan FBM HS diukur dengan rasio Jensen Alpha

\section{METODE PENELITIAN}

\section{Populasi, Sampel dan Teknik Sampling}

Populasi dalam penelitian ini adalah seluruh indeks saham Syariah di Bursa Efek Indonesia dan Bursa Malaysia. Pengambilan sampel dilakukan dengan menggunakan metode purposive sampling. yaitu sampel dipilih berdasarkan kesesuaian karasteristik dengan kriteria sampel yang ditentukan agar diperoleh sampel yang representatif. Kriteria tersebut adalah:
1. Indeks saham Syariah yang beroperasi pada Bursa Efek Indonesia dan Bursa Malaysia pada rentang waktu tahun 2009 hingga tahun 2011.

2. Indeks saham Syariah yang memiliki emiten 30 saham Syariah dengan likuditas dan kapitalisasi pasar terbaik.

Dari kriteria tersebut diperoleh sampel Jakarta Islamic Index pada Bursa Efek Indonesia dan FTSE Bursa Malaysia Hijrah Syariah Index pada Bursa Malaysia.

\section{Variabel dan Definisi Operasional Variabel Penelitian}

\section{Variabel penelitian}

Model disusun dengan menggunakan tiga variable, yaitu rasio Sharpe, Treynor dan Jensen.

\section{Definisi operasional variabel penelitian}

\section{a. Rasio Sharpe}

Indeks kinerja Sharpe dihitung dengan formula sebagai berikut:

$$
\mathrm{Sp}=\frac{\mathrm{Rp}-\mathrm{Rf}}{\sigma p}
$$

Keterangan:

- Sp = indeks kinerja Sharpe.

- $\mathrm{Rp}=$ return portofolio atau tingkat pengembalian pasar.

- $\mathrm{Rf}=$ return bebas risiko tingkat bunga bebas risiko.

- $\sigma p=$ standar deviasi dari return portfolio $p$ selama waktu penelitian

\section{b. Rasio Treynor}

Indeks kinerja Treynor dihitung dengan formula berikut:

$$
\mathrm{Tp}=\frac{\mathrm{Rp}-\mathrm{Rf}}{\beta p}
$$




\section{Keterangan:}

- Tp = indeks kinerja Treynor.

- Rp = return portofolio atau tingkat pengembalian pasar.

- $\mathrm{Rf}=$ return bebas risiko tingkat bunga bebas risiko.

- $\beta p=$ risiko pasar dari portofolio atau risiko sistematik portofolio (Beta).

\section{Jensen Alpha}

Adapun formula Jensen ALPHA sebagai berikut:

$a p=R p-[R f+\beta p(R m-R f)]$

Semakin tinggi ap yang positif maka kinerja portofolionya semakin baik. Jensen ALPHA dapat dihitung dengan cara lain yaitu dengan menyederhanakan persamaan diatas menjadi persamaan dibawah ini:

$$
R p-R f=a p+\beta p(R m-R f)
$$

Keterangan:

$\mathrm{Rp}-\mathrm{Rf}=$ excess return (selisih return portofolio dengan risk free rate)

$\mathrm{Rm}-\mathrm{Rf}=$ market premium (selisih return market dengan risk free rate)

ap = ukuran dari security selection ability

$\beta p \quad=$ beta coefficient dari portofolio

Untuk menghitung ketiga variabel di atas, dibutuhkan beberapa komponen, yaitu:

\section{1) Return Indeks}

Return dihitung dengan cara mengurangi nilai indeks pada akhir unit periode tertentu $(\mathrm{t})$ dengan akhir

$$
\begin{array}{ll}
\quad & \text { Return }=\frac{P_{t}-P_{t-1}}{P_{t-1}} \text { Keterangan: } \\
\text { Pt } & =\text { Harga } \\
\text { Pt-1 } & =\text { Harga saham pada periode } t \text { (akhir periode) }
\end{array}
$$

\section{2) Standar Deviasi}

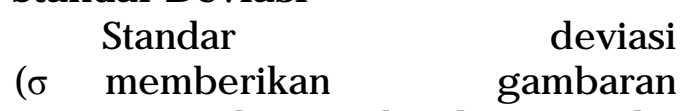

mengenai besar kecilnya risiko fluktuasi perubahan return per unit dari subperiode ke subperiode berikutnya, dan disebut sebagai risiko total. Semakin besar nilai $\sigma$ semakin tinggi risiko perubahan return per unit yang terjadi.

Perhitungan standar deviasi pada penelitian ini dilakukan terhadap tingkat pengembalian (return) seluruh reksadana syariah dan return pasar. Dalam program Microsoft Excel, perhitungan ini dapat dilakukan dengan formula "STDEV (...)". Begitu juga untuk perhitungan standar deviasi. Dalam penerapannya STDEV, perhitungan unit periode sebelumnya (t-1), kemudian dibagi dengan nilai indeks pada akhir unit periode sebelumnya (t-1). Jika dituliskan dalam bentuk persamaan adalah sebagai berikut:

\section{3) Risk Free Rate}

standar deviasi secara manual menggunakan rumus berikut:

$$
S=\sqrt{\sum \frac{\left(x_{1}-\bar{x}\right)^{2}}{n}}
$$

Keterangan:

$\mathrm{x}=$ data ke $\mathrm{n}$

$\mathrm{x}$ bar $=\mathrm{x}$ rata-rata $=$ nilai ratarata sampel

$\mathrm{n}=$ banyaknya data

Investasi yang bebas risiko (risk free asset) secara definisi memiliki return yang pasti, asset jenis ini harus berupa sekuritas berbunga tetap yang tidak memiliki kemungkinan default. Karena semua sekuritas perusahaan pada prinsipnya memiliki kemungkinan default, asset bebas risiko tidak dapat diterbitkan 
oleh perusahaan, tetapi harus sekuritas yang diterbitkan oleh pemerintah (Sharpe, 1997).

Dalam penelitian ini, investasi tanpa risiko diasumsikan merupakan tingkat kupon Surat Utang Negara (SUN) Seri FR0051 yang di-issue pada tanggal 22 Januari 2009 dengan jangka maturity 5,4 tahun yang didapatkan dari situs www.bi.go.id dan tingkat kupon Malaysian Government Security (MGS) Seri MH090001 yang di-issue pada tanggal 27 Februari 2009 dengan jangka maturity 1.277 hari $(3,5$ tahun) yang didapatkan dari situs www.bondinfo.bnm.gov.my.

Tingkat Bonus SUN dan MGS sudah dalam bentuk persentase sehingga perhitungan return keduanya dapat dilakukan dengan membagi tingkat bonus SUN dan MGS masing-masing dengan jumlah bulan hingga masa jatuh tempo (maturity) untuk menggambarkan tingkat pengembalian dalam basis bulanan.

\section{4) Beta}

Beta $(\beta)$ adalah risiko pasar
yang memberikan gambaran
hubungan antara excess return

$$
\beta i l=\frac{\sigma \mathrm{il}}{\sigma 2 \mathrm{l}}
$$

Keterangan:

$\beta \mathrm{il}=$ Beta portfolio

$\sigma \mathrm{il}=$ kovarians return portfolio i dengan portfolio pasar

$\sigma 2 I=$ varians dari portfolio pasar

\section{ANALISISDATA DAN PEMBAHASAN}

\section{Deskripsi Sampel}

Dari proses pengambilan sampel diperoleh dua indeks yang terdiri dari JII untuk Indonesia dan FBMHS untuk Malaysia. Untuk melakukan penelitian kinerja dua indeks tersebut, digunakan:

1. Return indeks yang diperoleh dari nilai penutupan mingguan nilai penutupan mingguan JII Indonesia portofolio dengan excess return dari pasar. Indeks dengan $\beta=1$ mempunyai risiko yang sama dengan risiko pasar (IHSG), sehingga diharapkan memperoleh return sama dengan yang dihasilkan oleh IHSG. Portofolio $\beta<1$ mempunyai risiko yang lebih kecil dari risiko pasar, sehingga potensi return yang didapat umumnya dibawah return yang dihasilkan IHSG. Indeks dengan $\beta>1$ mempunyai risiko yang lebih besar dari risiko pasar, sehingga diharapkan mempunyai return di atas return IHSG.

Perhitungan beta dalam penelitian adalah beta JII dan FBMHS sedangkan beta pasar tidak dihitung karena bernilai satu. Perhitungan beta dalam penelitian ini menggunakan regresi linier $Y=a+$ bX pada fungsi aplikasi Microsoft Excel dengan fungsi "SLOPE(...)" dengan ketentuan return JII dan FBMHS sebagai sumbu $Y$ dan return market sebagai sumbu X (IHSG untuk benchmark Indeks saham Indonesia dan FBMKLCl sebagai benchmark indeks saham Malaysia).

Dalam bentuk rumus, Beta dapat dihitung dengan menggunakan: dan FBMHS Malaysia selama periode tahun 2009-2011 untuk mengukur return indeks dan standar deviasi bulanan sebanyak 36 poin data.

2. Return pasar yang diperoleh dari nilai penutupan mingguan IHSG dan FBMKLCI Malaysia untuk mengukur return pasar dan Beta indeks JII dan FBM HS sebanyak 36 poin data.

3. Tingkat diskon Surat Utang Negara (SUN) Indonesia dan Malaysian 
Government Securities (MGS) Malaysia yang aktif pada periode 2009-2011 sebagai risk free rate.

Indikator kinerja keuangan yang digunakan dalam penelitian ini sebanyak 3 variabel, yaitu : Sharpe, Treynor dan Jensen Alpha

\section{Uji Normalitas}

Dari hasil uji normalitas dapat disimpulkan bahwa semua variabel dalam penelitian ini telah terdistribusi normal. Hal ini ditunjukkan dengan semua nilai Sig hitung >0,05.

\section{Pengujian Hipotesis}

Untuk menguji apakah ada perbedaan kinerja JII dan FBMHS dilakukan uji beda $t$ dua mean independen. Uji beda t test digunakan untuk menentukan apakah dua sampel yang tidak berhubungan memiliki nilai rata-rata yang berbeda. Uji beda $t$ dilakukan ddengan cara membandingkan perbedaan antara dua nilai rata-rata dengan standar error dari perbedaan rata-rata dua sampel atau secara rumus dapat ditulis sebagai berikut (Ghozali, 2011):

\section{T $=$\begin{tabular}{c} 
Rata-rata sampel pertama - rata-rata sampel kedua \\
\hline Standar error perbedaan rata-rata kedua sampel
\end{tabular}}

Standar error perbedaan dalam tidak berhubungan satu sama lain. nilai rata-rata terdistribusi secara normal. Apakah kedua grup tersebut mempunyai Jadi tujuan uji beda $t$ test adalah nilai rata-rata yang sama ataukah tidak membandingkan rata-rata dua grup yang sama secara signifikan.

\section{Rasio Sharpe}

Tabel 1. Hasil Uji Rasio Sharpe

\begin{tabular}{|c|c|c|c|c|}
\hline RASIO SHARPE & $\mathrm{N}$ & Mean & $\begin{array}{c}\text { Std. } \\
\text { Deviation }\end{array}$ & Sig (2 tailed) \\
\hline JII & 36 & 0.20295 & 1.212287 & 0.829 \\
FBMHS & 36 & 0.14519 & 1.044911 & \\
\hline
\end{tabular}

Berdasarkan tabel 1, signifikansi perbedaan kinerja JII dengan FBMHS pada aspek Sharpe adalah 0. 829, maka H1 ditolak dan Ho diterima, sehingga dapat disimpulkan tidak ada perbedaan signifikan antara kinerja FBMHS dengan JII pada aspek Sharpe.

\section{Rasio Treynor}

Tabel 2. Hasil Uji Rasio Treynor

\begin{tabular}{|c|c|c|c|c|}
\hline RASIO TREYNOR & $\mathrm{N}$ & Mean & $\begin{array}{c}\text { Std. } \\
\text { Deviation }\end{array}$ & Sig (2 tailed) \\
\hline JII & 36 & 0.00313 & .043312 & 0.597 \\
FBMHS & 36 & 0.00793 & .032622 & \\
\hline
\end{tabular}

Berdasarkan tabel 2, signifikansi perbedaan kinerja JII dengan FBMHS pada aspek Treynor adalah 0.597, maka Hl ditolak dan Ho diterima, sehingga dapat disimpulkan tidak ada perbedaan signifikan antara kinerja FBMHS dengan JII pada aspek Treynor. 


\section{Rasio Jensen}

Tabel 3. Hasil Uji Rasio Jensen

\begin{tabular}{|c|c|c|c|c|}
\hline RASIO JENSEN & $\mathrm{N}$ & Mean & $\begin{array}{c}\text { Std. } \\
\text { Deviation }\end{array}$ & Sig (2 tailed) \\
\hline JII & 36 & -0.00235 & 0.0078036 & 0.321 \\
FBMHS & 36 & -0.00033 & 0.009259 & \\
\hline
\end{tabular}

Berdasarkan tabel 3, signifikansi perbedaan kinerja JII dengan FBMHS pada aspek Jensen adalah 0.321, maka H1 ditolak dan Ho diterima, sehingga dapat disimpulkan tidak ada perbedaan signifikan antara kinerja FBMHS dengan JII pada aspek Jensen.

\section{PEMBAHASAN}

Penelitian ini dilakukan dengan memfokuskan pengungkapan ada atau tidaknya perbedaan antara kinerja FBMHS dengan JII melalui rasio-rasio Sharpe, Treynor dan Jensen Alpha. Hasil penelitian pada periode tersebut mengindikasikan hal-hal sebagai berikut:

\section{Perbedaan kinerja FBM HS dan JII diukur dengan rasio Sharpe}

Tidak ada perbedaan signifikan antara kinerja FBMHS dan JII $\alpha=0.05$ dengan nilai Sharpe JII yang mengungguli FBMHS. Kinerja Sharpe mengukur seberapa besar excess return (penambahan investasi) yang dihasilkan dari setiap portofolio untuk setiap unit total risk. Nilai kinerja Sharpe yang semakin besar akan memperlihatkan kinerja portofolio yang lebih baik.

Dengan melihat hasil pada pengukuran kinerja Sharpe yang positif pada kedua indeks, dapat dilihat bahwa JII dan FBMHS mampu memberikan excess return positif untuk setiap unit total risk yang dimiliki. JII memiliki nilai Sharpe yang lebih besar jika dibandingkan dengan FBMHS, maka excess return JII lebih besar dibanding FBMHS untuk setiap unit total risk.

Artinya keuntungan berinvestasi pada saham-saham FBMHS dan JII lebih besar dibanding keuntungan investasi pada aset bebas risiko (SUN dan MGS), namun keuntungan investasi pada JII lebih besar dari keuntungan FBMHS jika dilihat dari risiko total tiap indeks tersebut. Meski demikian, tidak ada perbedaan signifikan pada nilai rasio Sharpe kedua indeks.

\section{Perbedaan kinerja FBM HS dan JII diukur dengan rasio Treynor}

Tidak ada perbedaan signifikan antara kinerja FBMHS dan JII $\alpha=0.05$ dengan nilai Treynor FBMHS yang mengungguli JII. Indeks JII dan FBMHS memiliki indeks Treynor positif. Nilai positif ini disebabkan tingkat return JII dan FBMHS yang lebih tinggi dari return aset bebas risiko (SUN dan MGS).

FBMHS memiliki kinerja Treynor yang lebih tinggi dari JII, hal tersebut menunjukkan bahwa excess return yang dihasilkan oleh investasi pada FBMHS lebih besar dari JII untuk tiap unit systematic risk (risiko indeks yang dipengaruhi oleh risiko pasar) yang timbul pada setiap indeks. Meski demikian, tidak ada perbedaan signifikan pada nilai rasio Treynor kedua indeks.

\section{Perbedaan kinerja FBMHS dan JII diukur dengan rasio Jensen}

Tidak ada perbedaan signifikan antara kinerja FBMHS dan JII $\alpha=0.05$ dengan nilai Jensen FBMHS yang mengungguli JII. Pengukuran kinerja Jensen atau alpha ratio didasarkan pada teori Capital Asset Pricing Model (CAPM), yaitu membandingkan excess return dengan required return predicted dari CAPM.

FBMHS dan JII memiliki nilai Jensen yang negatif, hal tersebut 
menunjukkan bahwa kinerja FBMHS dan JII berada di bawah Expected Return. Meski demikian, tidak ada perbedaan signifikan pada nilai rasio Jensen kedua indeks.

\section{SIMPULAN}

Berdasarkan uraian pada analisis data dan pembahasan dapat disimpulkan halhal sebagai berikut:

1. Tidak ada perbedaan signifikan antara kinerja FBMHS dengan JII pada Rasio Sharpe.

2. Tidak ada perbedaan signifikan antara kinerja FBM HS dengan JII pada Rasio Treynor.

3. Tidak ada perbedaan signifikan antara kinerja FBM HS dengan JII pada Rasio Jensen.

\section{Keterbatasan Penelitian}

Penelitian ini hanya meneliti kinerja indeks saham Syariah, sehingga tidak dapat digeneralisir pada indeksindeks saham konvensional yang terdaftar pada Bursa Efek Indonesia dan Bursa Malaysia.

\section{Saran}

Berdasarkan kesimpulan dari hasil penelitian, ada beberapa saran yang mungkin berguna bagi investor dan bagi penelitian selanjutnya.

\section{Saran bagi investor}

a. Hasil penelitian ini dapat dijadikan referensi bagi investor yang berminat untuk menanamkan dananya pada saham-saham Syariah di Indonesia dan Malaysia. Meski ada perbedaan hasil perhitungan rasio Sharpe, Treynor dan Jensen, di mana JII lebih unggul dari FBMHS pada rasio Sharpe yang menunjukkan bahwa excess return pada saham-sahamsaham emiten JII lebih lebih besar dari saham-saham emiten FBMHS untuk setiap risiko total indeks, serta FBMHS mengungguli JII pada rasio Treynor dan Jensen yang artinya untuk treynor excess return
FBMHS lebih besar di JII untuk setiap unit systematic risk (sensitifitas indeks secara individu terhadap risiko pasar) dan untuk Jensen bahwa return FBMHS lebih besar dari Jll meski sama-sama di bawah return yang diharapkan, namun tidak ada perbedaan signifikan antara kedua indeks pada tiga rasio tersebut. Untuk itu, keputusan investasi tetap menyesuaikan dengan kecenderungan manajer investasi.

b. Selain menggunakan hasil penelitian ini, investor hendaknya tetap memantau kinerja setiap saham emiten JII dan FBMHS yang akan dijadikan instrumen investasi untuk melihat kinerja sahamsaham tersebut secara individu.

2. Saran bagi penelitian selanjutnya

a. Karena keterbatasan data Indeks yang dimiliki oleh penulis, sebaiknya data temuan dari penelitian ini diujicobakan pada pencapaian return indeks tahun selanjutnya untuk mengetahui apakah data temuan tersebut masih relevan atau tidak.

b. Hendaknya penelitian mengenai kinerja indeks selanjutnya dapat menggunakan rasio-rasio lain selain yang digunakan penulis dalam rangka menambah akurasi penelitian, terutama rasio-rasio terkait penilaian portofolio.

\section{DAFTAR PUSTAKA}

Albaity, M., dan A. Rubi. 2008. Performance of Syariah And Composite Indices: Evidence from Bursa Malaysia. Asian Academy of Management Journal of Accounting and Finance 4 (1): 23-43.

Bapepam-LK. 2012. Statistik Pasar Modal Syariah.

http://www.bapepam.go.id/syariah Lstatistik/pdf/2012/Statistik_Saham Lanuari.pdf diakses 4 Juli $20 \overline{1} 2$.

Bapepam-LK, dan DSN-MUI. 2010. Himpunan Peraturan Bapepam-LK 
Tentang Pasar Modal Syariah dan Kumpulan Fatwa DSN-MUI terkait Pasar Modal Syariah. Jakarta: Bapepam-LK.

Boston Consulting Group. 2011. Shaping a New Tomorrow. Boston: Boston Consulting Group

Christian, F. 2009. Evaluasi Kinerja Reksadana Saham Pada Kondisi Bullish dan Bearish. Tesis. Jakarta: Universitas Ind onesia

Dharani, M., dan P. Natarajan. 2011. Equanimity of Risk And Return Relationship Between Shariah Index And General Index In India. Journal of Economics and Behavioral Studies, 2 (5): $213-222$.

Ferdian, I. R; M. K. Dewi; dan H. F. Riany. 2008. The Performance Analysis of Islamic Stocks- a Comparative Study Between Indonesia and Malaysia. Working Paper. Surabaya: IAEI International Conference. http://www.scribd.com/doc/656572 32/Ilham-Reza-Ferdia-STock diakses 23 Februari 2012.

FTSE, 2012. Ground Rules For The Management of The FTSE Bursa Malaysia Index Series. London: FTSE

Hassan, M. K. dan E. Girard. 2011. FaithBased Ethical Investing: the Case of Dow Jones Islamic Indexes. Working paper. Indiana: Indiana State University.

Hussein, A. K. 2004. Ethical Investment: Empirical Evidence from FTSE Islamic Index. Islamic Economic Studies, 12 (1): 21-40.

Indiastuti, F. 2008. Evaluasi Terhadap Kinerja Reksa Dana Saham dan
Pembentukan Portofolio Optimal pada Instumen Reksa Dana Saham. Tesis. Jakarta: Universitas Indonesia

Jogiyanto, H. 2011. Teori Portofolio dan Analisis Investasi (Edisi 7). Yogyakarta: BPFE Yogyakarta

Reilly, F. K., dan E. A. Norton. 2006. Investments, Seventh Edition. Ohio: Thompson South Western

Reilly, F. K., dan K.C. Brown. 1999. Investment Analysis and Portfolio Management. Ohio: Thompson South Western

Ross, S. A.; R. W. Westerfield; dan J. F. Jaffe. 2005. Corporate Finance, Sixth Edition, New York: The McGraw-Hill Companies

Malaysia, Syaria Advisory Council. 2011. Malaysian ICM, 3rd Quarter 2011. Kuala Lumpur: Securities Commission Malaysia.

Sharpe, W. F. 1997. Portfolio Theory and Capital Market. New York: Mc Graw Hill.

Tandelilin, E. 2010. Portofolio dan Investasi: Teori dan Aplikasi. Yogyakarta: Penerbit Kanisius

Tony, A. 2004. Analisis Perbandingan Kinerja Portofolio (Studi Kasus: Indeks Syariah dan Indeks Konvensional). Tesis. Jakarta: Universitas Indonesia

Walkshäusl, C. dan S. Lobe. 2011. Islamic Index Investing: the International Evidence. Abstract Academic Paper. Vallendar: WHU-Otto Beisheim School of Management. 
Jurnal Bisnis \& $M$ anajemen

Vol. 14, N o. 2, 2014 : 19 - 34 